\section{Evidence for a major Tertiary dyke swarm in County Fermanagh, Northern Ireland, on digitally processed aeromagnetic imagery}

\author{
P. J. GIBSON ${ }^{1} \&$ P. LYLE ${ }^{2}$ \\ ${ }^{1}$ Department of Geography, St Patrick's College, \\ Maynooth, County Kildare, Ireland \\ ${ }^{2}$ Department of Civil Engineering and Transport, \\ University of Ulster, Jordanstown BT37 OQB, \\ Northern Ireland
}

\begin{abstract}
Digitally processed aeromagnetic imagery has revealed an extensive swarm of reversely magnetized Tertiary dykes in County Fermanagh, Northern Ireland, $50 \mathrm{~km}$ west of the main outcrop of the Tertiary Antrim Lava Group. The swarm covers an area $>2000 \mathrm{~km}^{2}$, and ground magnetometer profiles across one example near Enniskillen show a negative anomaly of $c .2000 \mathrm{nT}$. Synergistic display of the available gravity and aeromagnetic data for the area shows a close coincidence between the Dromore gravity high and this dyke swarm and suggests the presence of a basic intrusive body at depth as the source of the magma for the dykes.
\end{abstract}

The presence of dolerite dykes in County Fermanagh some $50 \mathrm{~km}$ to the west of the main outcrop of the Tertiary Antrim Lava Group has been commented on by Preston (1967) and recorded by the Geological Survey of Northern Ireland (1977). A positive gravity anomaly between Omagh and Enniskillen on the line of the Donegal-Kingscourt dyke swarm was noted by Cook \& Murphy (1952) and interpreted by Preston (1967) as a Tertiary basic intrusive centre with the dykes acting as feeders to tholeiitic lava flows, since eroded. The very limited exposures in County Fermanagh mean that the full extent of the dykes cannot be ascertained by field mapping alone, but digitally processed aeromagnetic data show that they are much more extensive than is indicated by their occurrence in outcrop. Larsen (1978) used similar aeromagnetic techniques in the investigation of offshore dykes in the north Atlantic, and Carruthers et al. (1991) used ground magnetometer traverses to locate dykes in poorly exposed terrain. The conventional representation of aeromagnetic data as a contoured plot has been superseded by their display in an image format for a number of reasons. An image shows the entire continuum of intensity variations rather than fixed contour levels. In addition, the human visual system evolved to extract information from an 'image' and not from values associated with specific lines. This approach has been used successfully for structural interpretations in Britain (Lee et al. 1980; Drury \& Walker 1987 ) and in northeast Ireland (Gibson \& Lyle 1992).

A total of 19546 aeromagnetic data points within an area of $130 \mathrm{~km} \times 130 \mathrm{~km}$ in Northern Ireland were rescaled, interpolated onto a regular grid with a pixel dimension of $260 \mathrm{~m}$ and displayed on an image processing system with each pixel being assigned a grey-scale value dependent on its associated digital number. The results of this processing are shown on Fig. 1 in which the darkest tones represent the lowest aeromagnetic values. Based on tonal and textural variations the image can readily be divided into four magnetic regions.

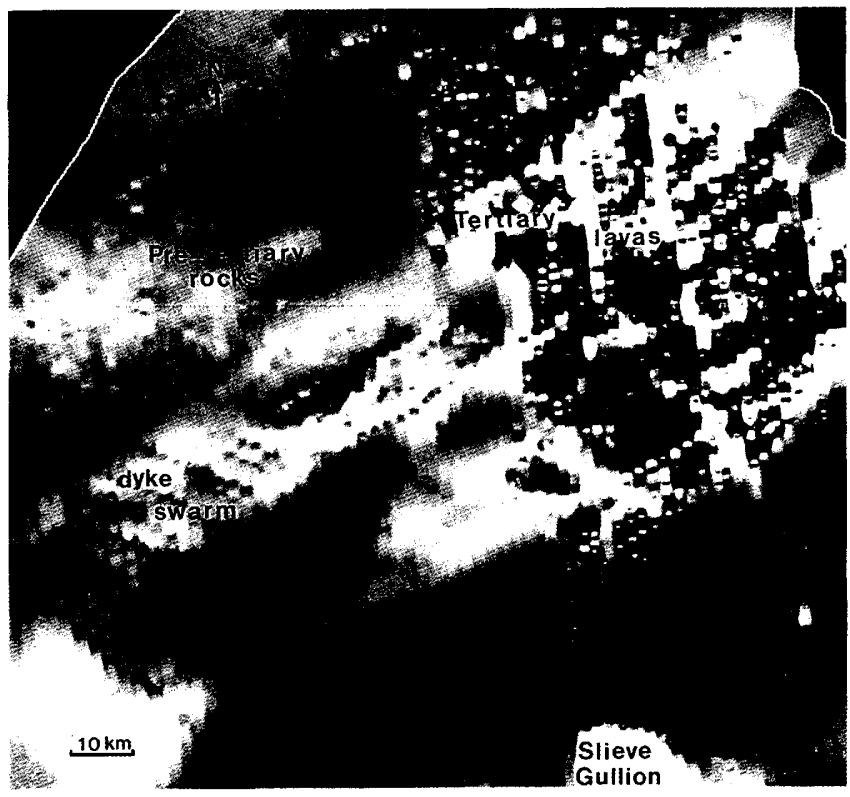

Fig. 1. Aeromagnetic image of Northern Ireland $(130 \mathrm{~km} \times$ $130 \mathrm{~km}$ ) produced from digital data that has been interpolated onto a regular grid array and displayed in a grey scale format. The lower the magnetic signature, the darker the image. The mega-dykes are shown as dark lineaments in the southwest. Fig. 2 gives the location and interpretation.

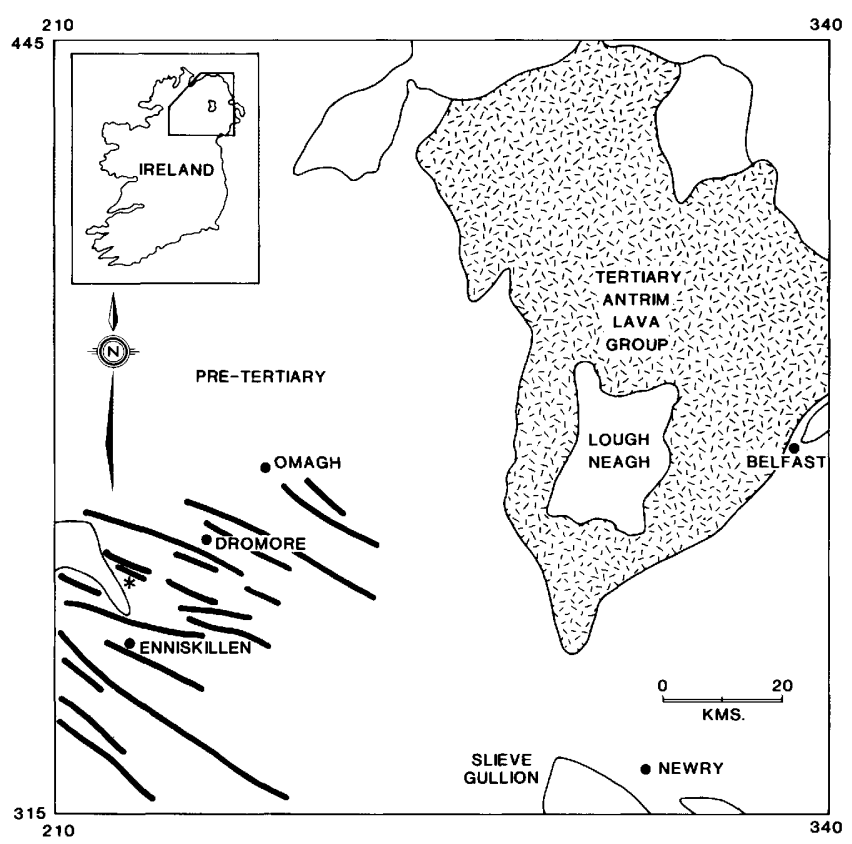

Fig. 2. Interpretation of the main geological features of the aeromagnetic image of Northern Ireland in Fig. 1 The frame corresponds approximately with Fig. 1 and the coordinates refer to the Irish Grid. The asterisk shows the location of the magnetometer traverse across the mega-dyke at Doonan Quarry in September 1990 (Fig. 3).

(1) The western half of Fig. 1 is represented by a range of grey values that vary smoothly. These areas are essentially nonmagnetic Dalradian metasedimentary rocks or OrdovicianCarboniferous sedimentary rocks. 
(2) A bright elliptical feature aligned NW-SE in the southeast is the Tertiary ring complex at Slieve Gullion.

(3) The Tertiary Antrim Lava Group crops out in the northeast (Fig. 2) and the basalts possess a high remanent magnetism. The lavas produce a high frequency tonal variation which is in sharp contrast to the non-magnetic lithologies to the west. The tone is generally dark which is consistent with their known reverse magnetism (Wilson 1970). Bright lineaments represent faults.

(4) The Fermanagh dykes in the southwest are shown as dark linear features up to $40 \mathrm{~km}$ in length and which cover an area of $>2000 \mathrm{~km}^{2}$. They are associated with a dark signature indicating that, like the basalts to the east, they are reversely magnetized. The dykes feature prominently on this image in contrast to the published aeromagnetic contour map because of the wider contour interval used in the map, and because the modulation transfer functions of the human visual system enable high contrast linear features to be detected on monochromatic imagery (Drury 1986).

The petrography of one of the largest Tertiary dykes in Fermanagh, at Doraville, has been described in detail by Preston (1967). It forms a low ridge along the NE shore of Lough Erne and is traceable for $>5 \mathrm{~km}$. Exposures in Doonan Quarry along this ridge show the dyke to be at least $80 \mathrm{~m}$ wide at this point. A ground magnetometer traverse was made across this dyke in September 1990 (location shown by asterisk on Fig. 2) and the results are shown in Fig. 3. The dyke is associated with a sharply defined negative anomaly of $2000 \mathrm{nT}$ which is consistent with its associated dark aeromagnetic signature. With dyke widths of around $100 \mathrm{~m}$ these Fermanagh dykes are approximately an order of magnitude greater than those associated with the Antrim lava plateau to the east. To emphasize this difference they have been informally termed 'mega-dykes' in this study.

A synergistic display of the gravity and aeromagnetic images shows that the mega-dykes are concentrated over a positive gravity anomaly (Gibson 1992). Modelling of this gravity anomaly suggests it is caused by an intrusive igneous body with a density of $2.85 \mathrm{Mg} \mathrm{m}^{-3}$ whose top is $3 \mathrm{~km}$ below the surface (Gibson 1991).

Volcanological implications. It is not possible at this stage to establish whether these dykes were in fact feeders to lava flows since eroded, as suggested by Preston (1967), but the apparent existence of an extensive dyke swarm associated with a major intrusive centre, located between the main Tertiary centres of Antrim and Down and those of the west of Ireland and offshore represents a substantial addition to the Irish Tertiary Igneous Province and is worthy of further investigation. This new centre is en echelon with the Tertiary ring complexes of Carlingford and Slieve Gullion around $60 \mathrm{~km}$ to the southeast (Fig. 2) and occurs along the line of the previously recognized DonegalKingscourt dyke swarm. Significant differences in geochemistry have been described between the Tertiary basaltic rocks on Antrim and those of west-central Ireland (Mohr 1982, 1988). Magmas from the west of Ireland have a more alkaline composition than the essentially tholeiitic Antrim lavas and proposed future geochemical investigation of the Fermanagh intrusives may elucidate the overall magmatic relationships involved in the crustal evolution of the continental margin of Ireland during Tertiary times.

We are grateful to A. E. Griffith (Geological Survey of Northern Ireland) for the use of the magnetometer used in this study, to the

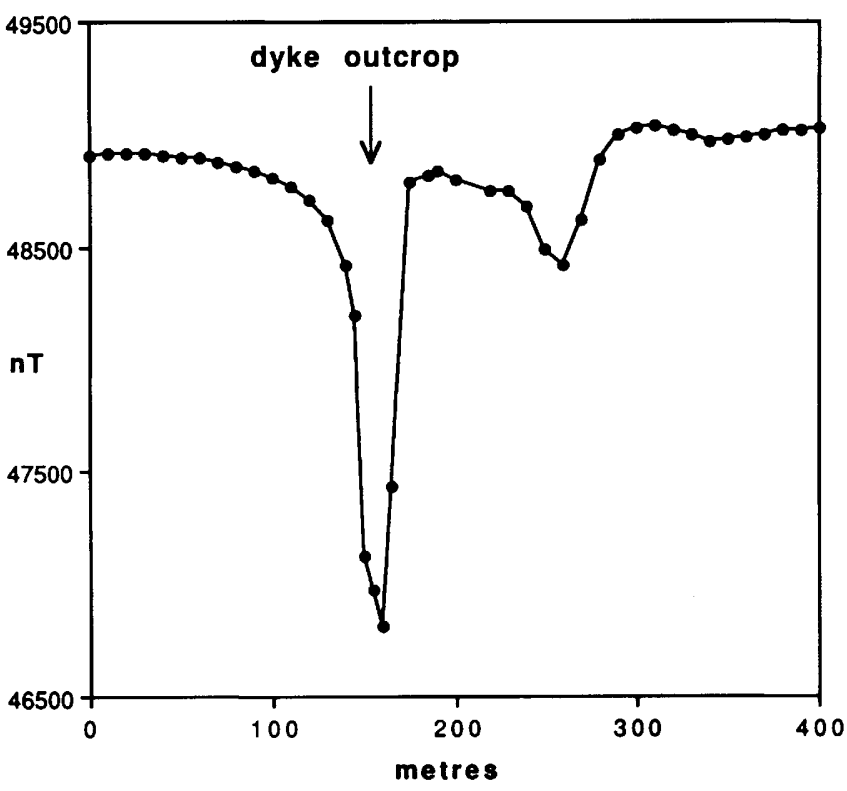

Fig. 3. Magnetic signature of the Doraville mega-dyke at Doonan Quarry, County Fermanagh, acquired using a Geometrics total field proton precession magnetometer. The dyke is reversely magnetized and is associated with a negative anomaly of around $2000 \mathrm{nT}$.

British Geological Survey for access to the geophysical data and to the Geology Department at University College, Dublin for access to their image processing program. P.J.G. acknowledges receipt of a postgraduate studentship from the Department of Education, Northern Ireland, held at the Department of Environmental Studies, University of Ulster, Coleraine.

\section{References}

Carruthers, R. M., Greenbaum, D., Peart, R. J. \& Herbert, R. 1991. Geophysical investigations of photolineaments in southeast Zimbabwe. Quarterly Journal of Engineering Geology, 24, 437-451.

Cook, A. H. \& Murphy, T. 1952. Measurements of gravity in Ireland. Gravity survey of Ireland north of the line Sligo-Dundalk. Dublin Institute of Advanced Studies, Geophysical Memoir, 2, 36.

DruRY, S. A. 1986. Remote sensing of geological structure in temperate agricultural terrains. Geological Magazine, 123, 113-121.

\& WAlker, A. S. D. 1987. Display and enhancement of gridded aeromagnetic data of the Solway Basin. International Journal of Remote Sensing, 8 , $1433-1444$.

Gibson, P. J. 1991. An integrated investigation of the Tow Valley Fault System with particular emphasis on remote sensing techniques. D Phil thesis University of Ulster.

1992. Evaluation of digitally processed geophysical data sets for the analysis of geological features in northern Ireland. International Journal of Remote Sensing, In press.

_ \& LYLE, P. 1992. The interpretation of a major non-Caledonian structural lineament in northeast Ireland. Irish Journal of Earth Sciences, In press.

Geological Survey of Northern Ireland 1977. Geological Map of Northern Ireland, Sheet 1, 1:250,000.

LARSEN, H. C. 1978. Offshore continuation of East Greenland dyke swarm and North Atlantic Ocean formation. Nature, 274, 220-223.

Lee M. K., Pharaoh, T. C. \& Soper, N. J. 1990. Structural trends in central Britain from images of gravity and aeromagnetic fields. Journal of the Geological Society, London, 147, 241-258.

Mohr, P. 1982. Tertiary dolerite intrusions of west-central Ireland. Proceedings of the Royal Irish Academy, 82B, 53-82.

- 1988. The analcime-olivine dolerites of west Connacht, Ireland: classification and genetic problems. Irish Journal of Earth Sciences, 9, 133-140.

Preston, J. 1967. A Tertiary feeder dyke in County Fermanagh, Northern Ireland. Scientific Proceedings of the Royal Dublin Society, 3(A), 1-16.

WILson, R. L. 1970. Palaeomagnetic stratigraphy of Tertiary lavas from Northern Ireland. Geophysical Journal of the Royal Astronomical Society, 20, 1-9. 